\title{
Women Managers and Entrepreneurs and Digitalization: On the Verge of a New Era or a Nervous Breakdown?
}

\author{
Mervi Rajahonka and Kaija Villman
}

\author{
(6) Even the biggest problems in the world are just tiny problems ") \\ stuck together.
}

\author{
Linda Liukas \\ Software Programmer and Co-Founder of Rails Girls \\ Author of Hello Ruby, a children's book that teaches coding \\ One of Forbes' Top 50 Women in Tech Europe 2018
}

\begin{abstract}
The purpose of this article is to examine how female managers and entrepreneurs are employing digital technologies in their working and private lives and what they think about digitalization. The material for the study was gathered through interviews with women in South Savo, Finland. The article builds on the theory of technology domestication, emphasizing the role of users in making a technology usable in their everyday contexts. The findings show that women experience challenges but also gain clear benefits when employing digital technologies. Among the challenges is that women are traditionally rather reserved when it comes to applying technology. Among the benefits is the practice-oriented stance of women towards digital technologies. Moreover, the rise of digital social media and its increasing importance in the working and business environments could make it easier for women to manage both work- and family-related communication. This may improve their wellbeing at work and help women towards equality at work. However, they need support in finding their digitalized career paths.
\end{abstract}

\section{Introduction}

The diffusion of information and communication technology (ICT) has brought change to all aspects of our lives, not least our working lives. The digital economy has grown much faster than the rest of the economy; however, the rapid development of digital technologies has created challenges for inclusive growth. For example, there is an identified problem of under-representation of women in economically critical sectors such as ICTs (Pappas et al., 2017).

The purpose of this article is to study how women managers and entrepreneurs are employing digital technologies in their working and private lives and what they think about digitalization. Our research questions are: 1) How do digital competences shape the careers of women? 2) How are women using digital technologies?, and 3) What opportunities or threats do women have concerning digitalization when it comes driving career development and finding a balance between work and life? The focus of this article is on the relationship between digitalization and the careers and wellbeing of female managers and entrepreneurs. As far as we know, this is one of the first articles studying the relationship between digitalization and the careers and wellbeing of female managers and entrepreneurs.

The article is organized as follows. First, we review prior literature on women and technology, women as managers and entrepreneurs and ICT, and technology diffusion and domestication. Thereafter, we document the research methodology and data collection. Next, we discuss the empirical findings based on our interviews and discussions with women in South Savo, Finland. Finally, we present concluding remarks. 


\section{Women Managers and Entrepreneurs and Digitalization: On the Verge of a New Era or a Nervous Breakdown? Mervi Rajahonka and Kaija Villman}

\section{Literature Review}

\section{Women and technology}

The digital economy grows as such as rate that there is a constant lack of qualified ICT staff. In the European Union, initiatives to deal with this skills shortage highlight the need to activate the female population through training with a focus on ICT (Pappas et al., 2017). Traditionally, technology-related careers are linked to competences that are not commonly associated with women (Mora, 2015). Women represent about $50 \%$ of university students in most developed countries, but they are under-represented in the science, technology, engineering, and mathematics (STEM) fields (Waaijer et al., 2016). For younger children, there is no difference in the use computers but, at the age of 16 or 17, the gender gap grows (Dixon et al., 2014). Computer software is usually developed for (and by) males, which may explain why boys tend to find computers more appealing and more easily develop confidence in using them, at least generally. In addition, even when gender differences in skills are insignificant, women perceive their skills as being lower than those of their male counterparts (Dixon et al., 2014; van Dijk, 2017.)

It is said there are "leaks" in the education pipeline of women, as evidenced by girls with higher mathematical skills not being as likely to enter STEM fields at university as boys with lower skills (Ferguson, 2016). Research has even shown that computer science is seen as a domain for men according to cultural beliefs and that some males respond by "chasing" girls and women away from the field (Michell et al., 2017). Consequently, women currently represent only $30 \%$ of ICT workers in Europe and have created only 9\% of ICT applications (Pappas et al., 2017). This is a contradiction because research indicates that women are more creative than men and that a strong female presence in business leads to more effective decisions (Pappas et al., 2017).

\section{Women as managers and entrepreneurs in a digital context}

In general, women are under-represented at the highest levels of organizations, receiving lower pay and fewer promotions than men (Joshi et al., 2015). In the European Union in 2016, only $33 \%$ of managers were women (European Union, 2017). Also, women managers in Europe earn less compared to their male peers: when comparing different professions, managers had the largest differences in hourly earnings $(23 \%$ lower for women) (European Union, 2017). Women face both "glass ceiling" and "sticky floor" problems: whereas the glass ceiling is an obstacle for highly educated women, the sticky floor is a problem for less-educated women (Ahmad \& Naseer 2015). It has been claimed that being more qualified may be a woman's best hope, although having an education does not necessarily bring women the same benefits that it brings men (Ahmad \& Naseer, 2015; Mora, 2015).

Moreover, when women choose male-dominated work, they do not "fit" the expectations and may face bias: women may be seen as less able (e.g., having lower leadership skills) or less effective than men (Joshi et al., 2015). Furthermore, peers or superiors may discount women's efforts. In their research spanning many industries and occupations, Joshi and colleagues (2015) found that gender-based differences in organizational rewards were almost 14 times larger than gender-based differences in performance evaluations. It has also been claimed that the common perception of women being more risk averse than men causes women taking risks to either be disregarded or seen negatively as "cocky" (Jewell, 2011). Considering all the above mentioned, women's rare high positions in organizations have a great symbolic value for other women (Jewell, 2011; Joshi et al., 2015).

Women in the European Union earn, on average, around $16 \%$ less than men, but computer skills have a significant impact on pay that is slightly greater for women (5.3\% for men, $6 \%$ for women) (European Union, 2017; Pappas et al., 2017). Therefore, learning digital skills can be seen as especially beneficial for women with respect to their careers.

According to the Statistical Data on Women Entrepreneurs in Europe, female entrepreneurs represent about $30 \%$ of entrepreneurs in Europe (European Commission, 2014; Pappas et al., 2017). It has been stated that women increasingly start their own businesses as a way of avoiding the "glass ceiling". This effect can be seen in, for example, in Canada and Norway, where women start about $60 \%$ of all new businesses (Afrah \& Fabiha, 2017). Moreover, women form the clear majority $(78 \%)$ in oneperson businesses in Europe (Pappas et al., 2017). Digital technologies are transforming how business is done, opening up opportunities for entrepreneurs - including women entrepreneurs -to enter global value chains. Therefore, digitalization and use of ICT increase opportunities for women entrepreneurs to develop themselves and their businesses and to gain access to equal opportunities with men in business development (Afrah \& Fabiha, 2017; Pappas et al., 2017; Shah \& Saurabh, 2015). Even new concepts based on this notion have 


\section{Women Managers and Entrepreneurs and Digitalization: On the Verge of a New Era or a Nervous Breakdown? Mervi Rajahonka and Kaija Villman}

been suggested, such as the "Female Digital Entrepreneur", who has been defined as "a female entrepreneur who explores market opportunity exploiting the digital space to create something new" (Scuotto et al., 2019).

However, there are also challenges that women face in their careers. It has been noted that female entrepreneurs, more often than their male peers, experience a lack of time or human resources or challenges in receiving funding, such as start-up capital (Jewell, 2011; Sinell et al., 2018). Further, women are generally more family-oriented compared to men. Also, societal expectations still load most of the responsibility for social reproduction (e.g., preparing food, cleaning, taking care of children and elderly family members) to women, constraining their career development (Jewell, 2011). In the European Union, this effect can be seen in statistics from 2016: $79 \%$ of women cooked or did household work and $92 \%$ took care of their children on a daily basis, compared with $34 \%$ and $68 \%$ of men (European Union, 2017).

Also in 2016 in the European Union, 32\% of women in employment worked part-time, compared with $9 \%$ of men, and the employment rate of women with three or more children was $55 \%$, compared with $84 \%$ for men in the same situation (European Union, 2017). Also, other kinds of "non-standard working arrangements", such as hybrid entrepreneurship combining employment and entrepreneurship, have been claimed to be attractive approaches for females (Solesvik, 2017).

Digital technologies have led to work becoming more flexible, in general, and have blurred the borders between work and free time (Grönlund \& Öun, 2018). This creates opportunities and challenges for women in terms of how to integrate work and family responsibilities. Flexible work combined with the increasing usage of digital technologies could have positive impacts concerning the work-life balance for women. For example, it has been noticed that the usage of mobile phones has helped women manage and schedule their family affairs efficiently while working (Roy, 2016). Nevertheless, in our modern and flexible working lives, individuals are expected to be able to define and structure their own work and draw the line between their work and private lives. Research also suggests that women actually have less control than men over their work and schedules, and therefore it can be claimed that today's working life has not yet adapted to the expectations of modern women (Grönlund \& Öun, 2018.)
As technologies can be understood as tools or methods to accomplish certain tasks, they do not have any value as such, and they must fit into social contexts, which often are dynamic and gender-related. Huyer and Sikoska (2003) remind us that women need to be convinced that ICTs are useful to them. Also, because ICTs today are not gender neutral, they are not always appropriate to women's needs (Huyer \& Sikoska, 2003); at least not without proper adaptation.

\section{Technology diffusion and domestication}

Technology is an important driver of innovation. Innovation research has studied, among other issues, the diffusion of innovation, meaning the process through which innovations are adopted through a network of organizations (Rogers, 1995). Usually, this process has been described with a curve, where different types of users adopt innovations in different phases (Meade \& Islam, 2006). Yet, the adoption of technologies may not automatically lead to improvements for the adopting organizations, because new technology has to be combined with the organization's own activities (Hazen \& Byrd, 2012; West \& Bogers, 2014). This requires a compatible culture as well as technological knowledge to adapt innovations to the organization's own contexts (West \& Bogers, 2014).

The critics of the diffusion theory claim that it ignores the role of users in shaping or reshaping technologies (Deidre, 2007). The social construction of technology theory argues that technology is not merely "trickled down" or diffused, but it is socially shaped to different social contexts; furthermore, technology itself is shaping society and its contexts (Harwood, 2011). For example, gender shapes the construction and meanings of technology, but technology in turn also shapes gender roles. As an example, computer usage was originally strongly associated with men, but this situation began to change as women started to use computers. Therefore, the gender gap that was originally seen in overall computer and Internet use in the late 1990s had diminished by the late 2000s (Dixon et al., 2014.)

The theory of technology domestication is based on the idea of contexts, and it emphasizes the role of users in innovation and their efforts to make a technology usable in their daily lives. Domestication theory describes the process of how innovations, especially new technology, are "tamed" or reformed by the users to better fit their purposes. There are four phases in the domestication process: appropriation, objectification, incorporation, and conversion. In the appropriation phase, when 


\section{Women Managers and Entrepreneurs and Digitalization: On the Verge of a New Era or a Nervous Breakdown? Mervi Rajahonka and Kaija Villman}

a technology is sold to a user, ownership is central. In the objectification phase, the user tries to capture the value of the new technology, which involves spatial and temporal fittings (e.g., finding a place and time for the technology object in their home and life). The incorporation phase emphasizes how the object is used. The conversion phase is about the user's interpretations of the technology - how the user describes their relationship with the technology (Deidre, 2007; Silverstone et al., 1992).

Constructive and domestication approaches challenge the traditional roles of the active producer versus the passive user, and they call for a deeper understanding of how technologies are created, adopted, and used, and how they change over time (Harwood, 2011). According to these approaches, the use of technology involves social processes and learning to make the technology work. The "struggle" to make the technology work itself involves some degree of innovation (Harwood, 2011).

Based on his research on small business owners, Harwood (2011) remarks that entrepreneurs typically have to adapt technologies during their otherwise busy days; this is problematic because there are many important activities that frequently interrupt the domestication process, and entrepreneurs have to postpone the task for the next day's to-do list. Consequently, they also have to settle for tolerable solutions, as the "taming" cannot always be fully achieved. Further, business and private spaces may often blend together in the busy days for small business owners (Harwood, 2011).

\section{Research Design}

The material for the study was gathered through 40 individual interviews with female managers and entrepreneurs, and additional group discussions attended by 15 of the interviewed women plus 2 others, meaning the total sample was 42 women. Furthermore, the material includes timelines describing both personal and working lives of 14 of the women. All the material was gathered in South Savo, Finland, in 2017 and 2018. The data were collected mainly through face-to-face interview meetings. The 40 individual interviews were done at the beginning of two training and coaching programmes arranged by the DigiJoko project, and other material was gathered at the end of the programmes.

The aim of the DigiJoko project was to promote women's career paths, leadership, and female entrepreneurship in the digitalized working life. Measures of the project taken by South-Eastern Finland University of Applied Sciences Small Business Center included practice-oriented research on women's career paths presented in this article - and WoManager training and coaching programmes targeted to women who are currently in a leading position; who are moving up to a manager, team leader, or role with manager tasks; or who are entrepreneurs. The training and coaching programmes focused on strengthening women's leadership skills and networks and improving the success of women-led companies. A total of 62 women participated in the programmes. The DigiJoko project (3/2017-3/2019) was funded by the European Social Fund and the South Savo Centre for Economic Development, Transport and the Environment.

The study followed a multi-staged data analysis process, including coding of the data and theorizing the codes to link the collected data with theory. The interview and group discussion themes included digitalization, skills, career, working patterns, work-life balance, and wellbeing. Figure 1 illustrates the relationships between the main themes in the research.

The women worked in several sectors as entrepreneurs or managers in companies, associations, or public sector organizations. These women attended one of the two training and coaching programmes arranged especially for women to develop their leadership skills in

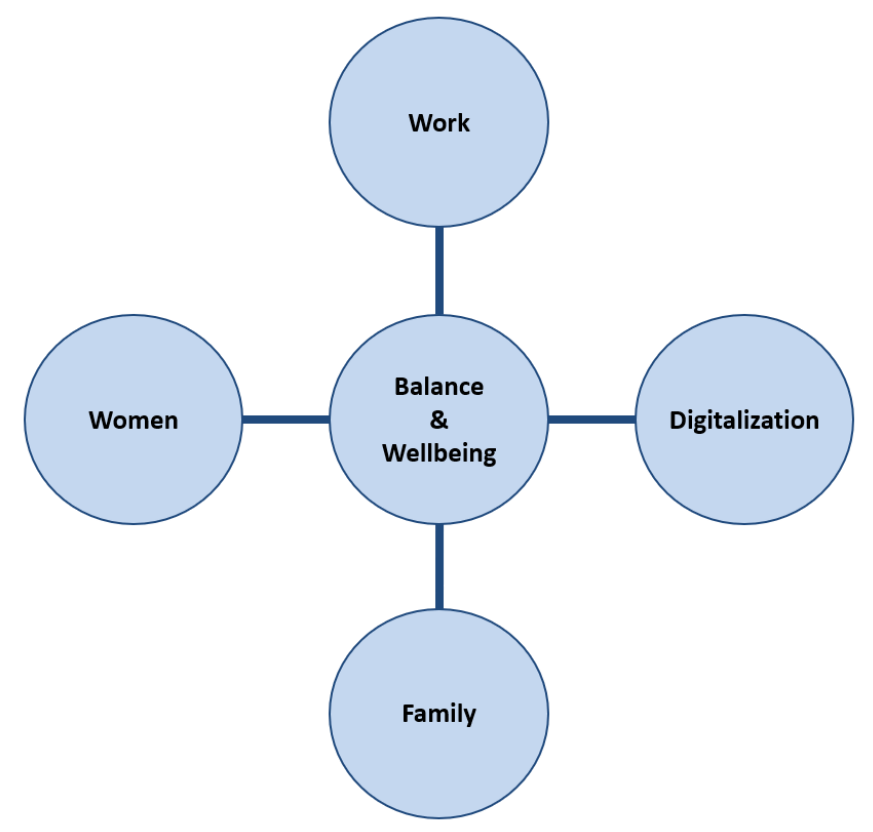

Figure 1. Relationships between the main themes in this research 


\section{Women Managers and Entrepreneurs and Digitalization: On the Verge of a New Era or a Nervous Breakdown? Mervi Rajahonka and Kaija Villman}

addition to skills and opportunities for using digital technologies at work. The identities of organizations and informants are withheld due to confidentiality reasons, although some background information about the interviewees is summarized in Table 1 . The backgrounds sectors represented by the interviewees were consulting (e.g., media, IT, finance), health and wellbeing, other services (e.g., education, tourism, transportation), and other (e.g., primary production, trade, industry).

\section{Findings and Discussion}

In the study, we investigated how female managers and entrepreneurs are employing digital technologies in their working and private lives and what they think about digitalization. We also studied the relationship between digital skills and career development and the wellbeing of women. In particular, we examined the challenges and opportunities women encounter when applying digital technologies at work.

The analysis of the interviews conducted at the beginning of the programme shows that the women's reasons for attending the training and coaching programme were diverse. Some of them wanted to find solutions for work-life balance and time management, while others wanted to increase their leadership skills or gain more self-confidence. Others wanted to get advice about how to recognize their current competences and competences they need to improve. Furthermore, important reasons to attend the programme were self-development and getting new ideas or practical tools usable in daily working life. In the first discussions, as a reason to attend the programme, most women mentioned that they wanted to develop their networks with other women working in different fields and to exchange experi- ences with them. Almost as important was the desire to improve skills in digital social media at work or to gain more knowledge about digitalization from a more strategic point of view, including the building of digital identity or brand, or related to the company's digital strategy. The need to improve digital skills was mentioned more often than management skills even though the programme was primarily a leadership training and coaching programme.

The women's actual digital skills at the beginning of the programme varied considerably. Some of them were just starting to use digital tools, whereas others had used them since the beginning of their careers. Specifically, some women had not used social media at work at all, whereas others were using social media fluently for different purposes. However, it was clear that all of the women wanted to improve their digital skills, regardless of how good their skills actually were. Some of the women already used digital technologies in their businesses, some even had online stores, while others used them for communication or marketing. Others emphasized that they wanted to learn to understand what the digital future looks like and how the world is changing.

The timelines as well as the group discussions at the end of the programme indicated that some women had had challenges in balancing their work and family lives. Many of them had stayed at home to take care of children for many years, usually at the beginning of their careers. Staying at home had interrupted their career development for several years. Continuing education -while simultaneously working - had been crucial for many of them to get back on track. Maybe because of that, constant further education while working had become a habit for many of them. Also, some women explained that their family had moved to another city

Table 1. Positions and organizational background of the women in this study

\begin{tabular}{lcccc}
\hline Background & Consulting & $\begin{array}{c}\text { Health and } \\
\text { Wellbeing }\end{array}$ & Other Services & Other \\
\hline Entrepreneur & 5 & 3 & 4 & 6 \\
\hline Manager, private company & 6 & 1 & 3 & 3 \\
\hline Manager, other organization & 4 & 0 & 1 & 0 \\
\hline Expert & 0 & 1 & 5 & 0 \\
\hline Totals & $\mathbf{1 5}$ & $\mathbf{5}$ & $\mathbf{1 3}$ & $\mathbf{9}$ \\
\hline
\end{tabular}




\section{Women Managers and Entrepreneurs and Digitalization: On the Verge of a New Era or a Nervous Breakdown? Mervi Rajahonka and Kaija Villman}

when their husband was hired for a new job or was relocated. Thus, the responsibilities of taking care of children and women typically being the secondary breadwinner of the family increase the demand for flexibility in women's careers. However, some of the women emphasized that the understanding and support of their families had been an important promoter of their careers. A generalized timeline based on 14 visualized timelines made by the interviewed women is presented in Figure 2.

In the group discussions at the end of the programme, motivations, careers, and work-life balance were discussed. Many of the women told us that they had made their choices based on intuition, but that their interests had also changed over time. Quite a few had multiple second- or third-level degrees or had received further training while working. Most of the women had university degrees, but only a couple had a degree in a STEM field. They also emphasized that developing oneself at work requires being open to new opportunities and going bravely into new projects, while not being afraid of challenges. The main idea is to be flexible and accept that it is not necessary to do the same work forever. Some of the women had altogether turned their careers around. For example, one lady, after starting a career in textile design, started business studies in accounting and begun to work as an employee in the health sector; and another, after graduating and working as an employee in the field of energy engineering, took over an online shop in a completely different field as an entrepreneur. Explanations for these radical decisions had been changes of interests but were also motivated by economical or family-related reasons.
Also, most of the women told us they had developed digital competences at work through "learning by doing". In particular, the mature women described digitalization as the biggest change in their entire working life. Many of them emphasized that it has been necessary to constantly keep up with the pace of digitalization, but most of them also underlined that digitalization had created great opportunities for them to advance in their careers. For most of the women, their perspective on technology is as a user and is practice-oriented; in other words, they need to "tame" the technology to fit the practical purposes of their lives. Many told us that they were currently actually seen as ICT experts in their workplaces - even though only a few had undertaken any formal schooling in it. It is obvious that the group of women selected in our study - and that participated in the training and coaching programme - was used to developing themselves at work. They had progressed well in their careers by not being afraid of challenges and by being open to new opportunities, often enabled by digitalization. Therefore, we may conclude that digitalization and women developing their digital skills create opportunities for women to advance in their careers.

Some examples of the viewpoints from the interviews and discussions are presented in Table 2. Furthermore, we produced a video of some illustrative examples of the interviews, which is publicly available at tinyurl.com/ WoManager (also see Figure 3).

However, the findings of our study also show that women have multiple challenges related to digital technologies. Our interviews suggest, for example, that it seems to be rather challenging to move from "a free-

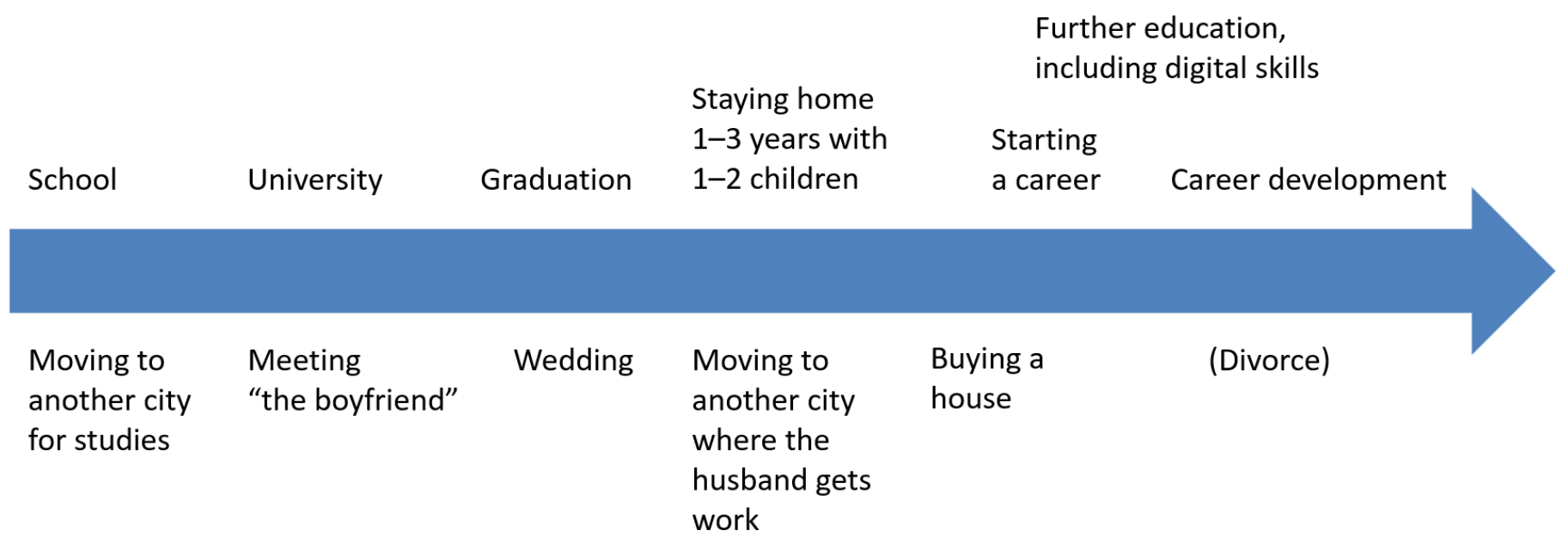

Figure 2. A generalized timeline of working women based on the 14 timelines gathered in the study 


\section{Women Managers and Entrepreneurs and Digitalization: On the Verge of a New Era or a Nervous Breakdown? Mervi Rajahonka and Kaija Villman}

Table 2. Some quotations from the interviews and discussions

\begin{tabular}{|c|c|}
\hline Theme & Quotation \\
\hline \multirow[t]{7}{*}{ Career } & $\begin{array}{l}\text { "In high school, I was a very good student, but physics and mathematics were impossible for me. So, I chose business } \\
\text { studies in university." }\end{array}$ \\
\hline & $\begin{array}{l}\text { "I only did my bachelor's degree first, and then went to work. After that, it was much more meaningful to study for the } \\
\text { master's degree, because I could compare theory and practice." }\end{array}$ \\
\hline & $\begin{array}{l}\text { "There have been millions of choices. When you are young, you just drift somewhere, but when you get older, you } \\
\text { become more aware of your choices." }\end{array}$ \\
\hline & "My life choice has been not to get stuck into my previous choices." \\
\hline & "The biggest choice in my career has been that I always hop into projects I cannot do and then learn by doing." \\
\hline & $\begin{array}{l}\text { "I established my own company, even though I was in a public office - although I liked my work, I wanted to do the work } \\
\text { in my own way." }\end{array}$ \\
\hline & "I have studied for 10 years at the same time I have been working, and it has a lot to do with my situation today." \\
\hline
\end{tabular}

Work-life balance

"We moved because my husband got a working place here. My work has to be flexible because of the family."

"After the maternity leave, I did not continue my old career because I had moved from a city to the countryside to live with my husband... I cannot see clear logics behind this choice, but my husband helped me with the decision to buy an online store."

"Now, as the children are still at home, this is a good situation, but after a few years I can think about other choices, somewhere else in Finland."

"It has been a balance between family and entrepreneurship. The youngest was seriously ill... We lost our dog ... and then there was the divorce."

"I have always been work-oriented, and luckily my husband has understood that."

"It is a challenge to take care of wellbeing because it is so easy to work with this". [talking about a smartphone]

"When you are an entrepreneur, there is nobody who would say that you have to take a holiday now."

"I have a lot of business trips, and it is challenging to balance the timetables of the family."

\section{Digital skills}

"I have been forced to learn digital competences at work, learning by doing... It has made work easier but brought more work, too."

"I have not used much [digital technologies], and I have always been a bit allergic about them, but along with my own entrepreneurship I should know more."

"Lack of digital competences would be very bad. My current role is due to the fact that I have had the interest... I'm a selftaught person."

"My career started when I just jumped as a greenhorn into the implementation project of a digital HR system and, suddenly, I was the main person responsible."

"Digital competences have been one of the greatest changes at work. There is always catching up there."

"On one hand, it is compulsory [to develop digital competences], and on the other hand, it enables one's development at work but also taking care of leisure time things."

"I have realized that I am a digi-wizard. I have studied humanities, but still I am the ICT support person at our working place."

"I cannot imagine my situation without digital competences. I have had my own web store for 10 years now." 


\section{Women Managers and Entrepreneurs and Digitalization: On the Verge of a New Era or a Nervous Breakdown? Mervi Rajahonka and Kaija Villman}

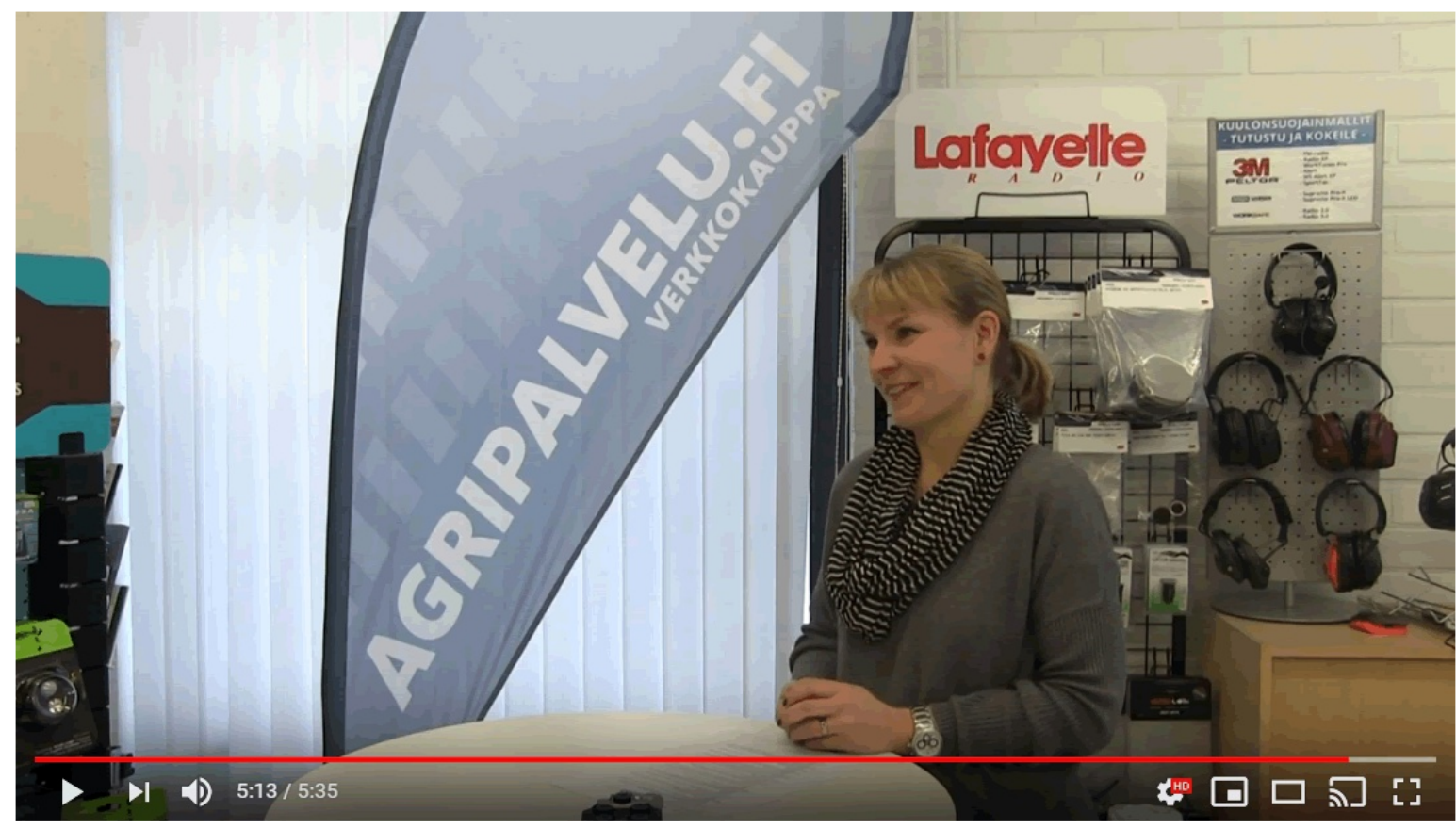

Figure 3. Screenshot of illustrative interviews available at: tinyurl.com/WoManager

time user" of social media to "a working user" and in that way fully "tame" social media. Nonetheless, longtime users of social media - typically younger women in the group - were used to move around in different channels and use the media for different purposes, easily combining work, family, and hobbies. However, the domestication of digital tools is not always easy and straightforward for everyone. Furthermore, social media and mobile tools create a great opportunity for women to find a balance between their work and family lives. However, this can also be a trap: if women do not know how to draw their own lines between their increasingly flexible digitalized work and their family lives, their wellbeing can be at stake, and burnout can be just around the corner.

In addition, our findings show that women need role models in advancing their career development in general, but also in promoting their usage of digital technologies at work and in their free time. We found that women sometimes lack self-confidence and trust in their own competences. Therefore, encouragement and support from other women in their network are of utmost importance. However, we may conclude that, for a woman, developing digital competences is an important means to accelerating her career. Digital tools, when properly domesticated and combined with appropriate self-management skills, increase both women's wellbeing and opportunities to develop and advance in their careers.
Figure 4 - revisiting our research themes - summarizes our main findings on the relationship between digitalization and women's careers and wellbeing (i.e., women's domestication process of digital technologies).

\section{Conclusion}

The focus of the study has been on the relationship between digitalization and the careers and wellbeing of female managers and entrepreneurs. The findings of our study confirm that women have challenges, but also clear benefits when employing digital technologies. Most of the interviewed women had positive attitudes towards digital technologies, and they thought that digital technologies had created great opportunities for them to advance in their careers.

The opportunities created by digital technologies are open for women, although most of them do not have STEM backgrounds. The varied backgrounds of women can even be seen as an advantage: by proceeding with learning by doing and by seeing technology as a means to an end, not an end in itself, they learn to translate the language of digital technologies into the language of organizations. When learning continuously changing digital technologies, one needs to have a positive attitude towards continuous lifelong learning. This is obvious for female managers and entrepreneurs because women are accustomed to developing themselves continuously while working. 


\section{Women Managers and Entrepreneurs and Digitalization: On the Verge of a New Era or a Nervous Breakdown? Mervi Rajahonka and Kaija Villman}

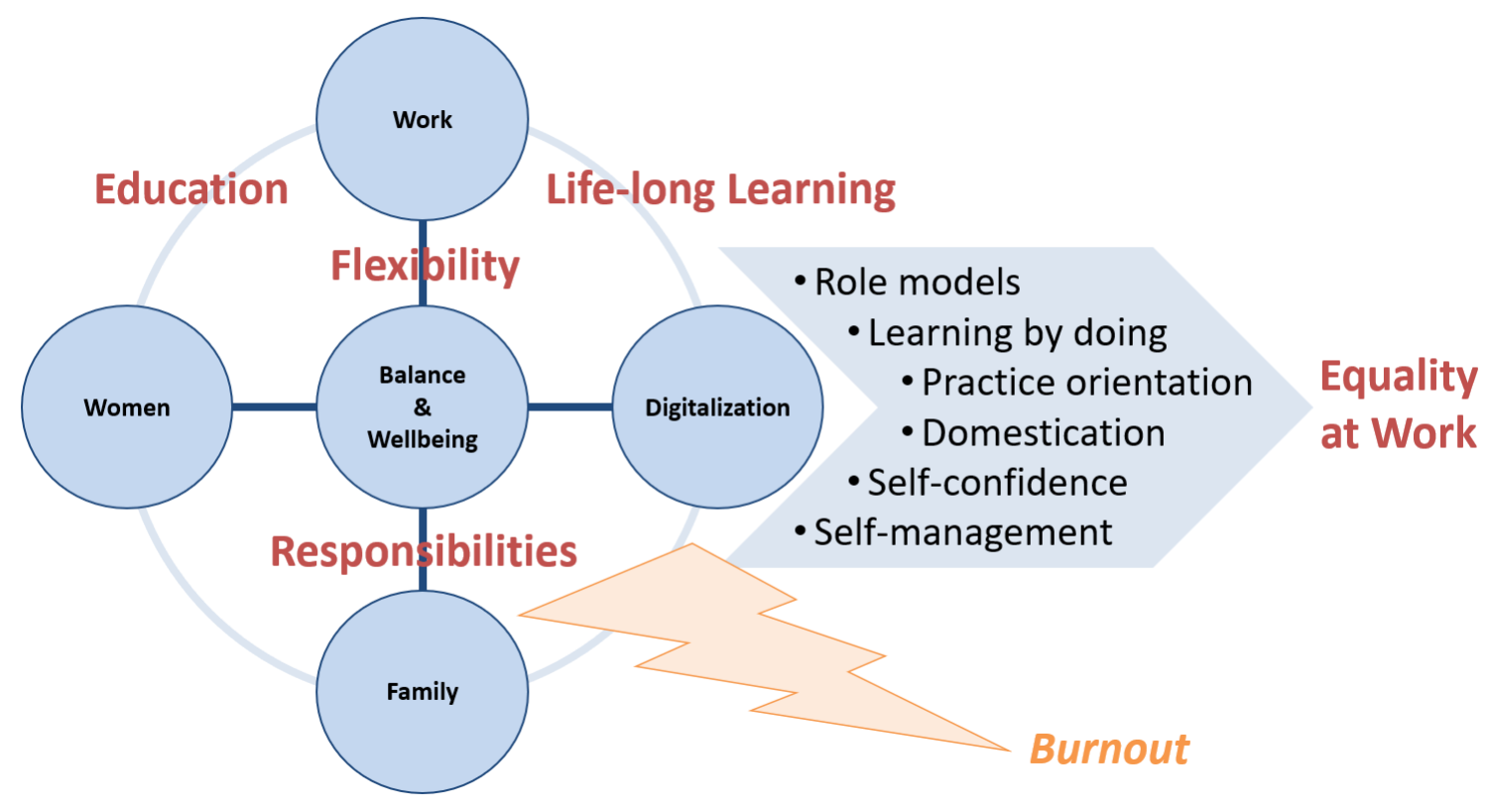

Figure 4. Main findings on working women's domestication process of digital technologies

Digitalization, especially social media and smartphones, and their increasing importance in working and business lives offer opportunities for women to fluently manage both work- and family-related communication. Yet, our findings indicate that digital tools must be properly domesticated and combined with self-management skills to be able to enhance both women's wellbeing and opportunities to develop and advance in their careers. However, taking these findings altogether, we conclude that digitalization creates opportunities for women to advance towards equality and prestige at work.

Our main findings and conclusions can be summarized with following points:

1. Women's careers - due to family responsibilities may bend and break; therefore, women learn flexibility.

2. Women managers and entrepreneurs develop themselves at work; they also develop their digital skills at work.

3. Women managers and entrepreneurs are practice-oriented in relation to digitalization.

4. Digitalization offers opportunities for career advancement, especially for women.
5. To avoid the danger of burnout, digital technologies have to be properly domesticated and combined with self-management skills.

6. Women need encouragement, role models, and networks to find their digital career paths.

There are also limitations in this study, as there are in any research. The empirical material of the study was gathered through interviews in South Savo, Finland. The data are rather limited and the conclusions are not widely generalizable, especially because the group of female managers and entrepreneurs selected to be in the study are from a rather privileged group in good positions and are interested in advancing their careers with the help of digital technologies.

The theoretical contribution of this research is pointing out the importance of contextual features related to digital technologies and discussing the domestication of digital technologies related to women managers and entrepreneurs. Innovation researchers and practitioners, especially those working with gender- or minority-related issues, may find the results of our study interesting.

The significance of contextual features in using technologies suggests that more research is needed on the 


\section{Women Managers and Entrepreneurs and Digitalization: On the Verge of a New Era or a Nervous Breakdown? Mervi Rajahonka and Kaija Villman}

work-life balance of women, and how the usage of digital technologies may help women find a proper balance between their working and private lives. It may be assumed that the contextual features and need for the domestication of digital technologies will probably increase in the future, as more and more digital tools will emerge, further increasing the complexity. Therefore, the theory of domestication is a promising theory for studying not only women, but also managers and entrepreneurs in general, and their relationship to technology. Most managers and entrepreneurs do not have STEM backgrounds but, instead, they have to deal with digital technologies while adapting - or taming - them in their own contexts, during the busy days of their lives. More research using this approach would be most welcome.

\section{Acknowledgements}

This research has been done as a part of the DigiJoko Digitalisation, women and management project (3/2017-3/2019), which is funded by the European Social Fund and the South Savo Centre for Economic Development, Transport and the Environment. The project aims to support the careers of women and enhance their entrepreneurship activities in their digitalized working lives. We have also received a grant from the Small Business Center Foundation for writing this article.

\section{References}

Afrah, S. H., \& Fabiha, S. T. 2017. Empowering Women Entrepreneurs through Information and Communication Technology (ICT): A Case Study of Bangladesh. Management, 7(1): 1-6. http://doi.org/10.5923/j.mm.20170701.01

Ahmad, M., \& Naseer, H. 2015. Gender Bias at Workplace: Through Sticky Floor and Glass Ceiling: A Comparative Study of Private and Public Organizations of Islamabad. International Journal of Management and Business Research, 5(3): 249-260.

Deidre, H. 2007. Applying Domestication: How the Internet Found Its Place in the Home. Managing Worldwide Operations \& Communications with Information Technology. In Proceedings of the 2007 Information Resources Management Association (IRMA) International Conference: 799-801. May 19-23, Vancouver, Canada.

\section{About the Authors}

Mervi Rajahonka, DSc (Econ), works as an RDI Advisor at the Small Business Center (SBC) at SouthEastern Finland University of Applied Sciences XAMK, Finland, and she is an Adjunct Research Professor at Carleton University in Ottawa, Canada. She has been working at SBC for about 10 years, participating in numerous EU-funded projects. She earned her doctoral degree in Logistics from the Department of Information and Service Economy at Aalto University School of Business in Helsinki, Finland. She also holds a Master's degree in Technology from Helsinki University of Technology and a Master's degree in Law from the University of Helsinki. Her research interests include business models, service modularity, and service innovations. Her research has been published in a number of journals in the areas of logistics, services, and operations management.

Kaija Villman, MMus in Arts Management, works as a Project Manager at the Small Business Center (SBC) at South-Eastern Finland University of Applied Sciences XAMK, Finland. She has been working at SBC for about 8 years, participating in numerous national and international EU-funded projects in the fields of creative industries, service development, and digitalization. She is experienced in coordinating interdisciplinary projects, workshops, and training and she acted as the Project Manager for the DigiJoko - Digitalisation, women and management project.
Dixon, L. J., Correa, T., Straubhaar, J., Covarrubias, L., Graber, D., Spence, J., \& Rojas, V. 2014. Gendered Space: The Digital Divide between Male and Female Users in Internet Public Access Sites. Journal of Computer-Mediated Communication, 19(4): 991-1009. https://doi.org/10.1111/jcc4.12088

European Commission. 2014. Statistical Data on Women Entrepreneurs in Europe. Brussels: European Commission.

European Union. 2017. The Life of Women and Men in Europe - A Statistical Portrait-2017 Edition. Brussels: European Union.

Ferguson, S. J. 2016. Women and Education: Qualifications, Skills and Technology. In Women in Canada: A Gender-based Statistical Report. Ottawa: Statistics Canada.

Grönlund, A., \& Öun, I. 2018. In Search of Family-Friendly Careers? Professional Strategies, Work Conditions and Gender Differences in Work-Family Conflict. Community, Work \& Family, 21(1): 87-105. https://doi.org/10.1080/13668803.2017.1375460 


\section{Women Managers and Entrepreneurs and Digitalization: On the Verge of a New Era or a Nervous Breakdown? Mervi Rajahonka and Kaija Villman}

Hazen, B. T., \& Byrd, T. A. 2012. Toward Creating Competitive Advantage with Logistics Information Technology. International Journal of Physical Distribution \& Logistics Management, 42(1): 8-35.

https://doi.org/10.1108/09600031211202454

Harwood, S. A. 2011. The Domestication of Online Technologies by Smaller Businesses and the 'Busy Day'. Information and Organization, 21(2): 84-106.

https://doi.org/10.1016/j.infoandorg.2011.03.002

Huyer, S., \& Sikoska, T. 2003. Overcoming the Gender Digital Divide: Understanding ICTs and their Potential for Empowerment of Women. INSTRAW Research Paper Series, No. 1. United Nations International Research and Training Institute for the Advancement of Women (INSTRAW).

Jewell, T. 2011. Redefining "Women's Work”: Tensions Between Technology, Entrepreneurship, and Social Reproduction. Open Source Business Resource, July 2011: 6-12.

http://timreview.ca/article/452

Joshi, A., Son, J., \& Roh, H. 2015. When Can Women Close the Gap? A Meta-Analytic Test of Sex Differences in Performance and Rewards. Academy of Management Journal, 58(5): 1516-1545. https://doi.org/10.5465/amj.2013.0721

Meade, N., \& Islam, T. 2006. Modelling and Forecasting the Diffusion of Innovation - A 25-Year Review. International Journal of Forecasting, 22(3): 519-545.

https://doi.org/10.1016/j.ijforecast.2006.01.005

Michell, D., Szorenyi, A., Falkner, K., \& Szabo, C. 2017. Broadening Participation Not Border Protection: How Universities Can Support Women in Computer Science. Journal of Higher Education Policy and Management, 39(4): 406-422. https://doi.org/10.1080/1360080X.2017.1330821

Mora, J. 2015. Women's Greater Educational Efforts as a Consequence of Inequality. Law, Ethics and Philosophy (LEAP), 3: 107-115.

Pappas, M. A., Papagerasimou, Y., Drigas, A., Raftopoulos, D., \& Nikolaidis, P. 2017. ICT-based Innovation and Employability for Women. International Journal of Engineering Pedagogy (IJEP), $7(2): 36-47$.

Rogers, E. M. 1995. Diffusion of Innovations. New York: Simon and Schuster.

Roy, G. 2016. Impact of Mobile Communication Technology on the Work Life Balance of Working Women - A Review of Discourses. Journal of Contemporary Management Research, 10(1): 79-101.
Scuotto, V., Serravalle, F., Murray, A., \& Viassone, M. 2019. The Shift Towards a Digital Business Model: A Strategic Decision for the Female Entrepreneur. In T. Tomos, N. Kumar, N. Clifton, \& D. Hyams-Ssekasi (Eds.), Women Entrepreneurs and Strategic Decision Making in the Global Economy. http://doi.org/10.4018/978-1-5225-7479-8.ch007

Shah, H., \& Saurabh, P. 2015. Women Entrepreneurs in Developing Nations: Growth and Replication Strategies and Their Impact on Poverty Alleviation. Technology Innovation Management Review, 5(8): 34-43.

http://doi.org/10.22215/timreview/921

Silverstone, R., Hirsch, E., \& Morley, D. 1992. Information and Communication Technologies and the Moral Economy of the Household. In R. Silverstone \& E. Hirsch (Eds.), Consuming Technologies: Media and Information in Domestic Spaces: 9-17. London and New York: Routledge.

Sinell, A., Müller-Wieland, R., \& Muschner, A. 2018. Gender-Specific Constraints on Academic Entrepreneurship and Engagement in Knowledge and Technology Transfer. Technology Innovation Management Review, 8(2): 15-26.

http://doi.org/10.22215/timreview/1136

Solesvik, M. Z. 2017. Hybrid Entrepreneurship: How and Why Entrepreneurs Combine Employment with Self-Employment. Technology Innovation Management Review, 7(3): 33-41. http://doi.org/10.22215/timreview/1063

van Dijk, J. A. G. M. 2012. The Evolution of the Digital Divide - The Digital Divide turns to Inequality of Skills and Usage. In J. Bus, M. Crompton, M. Hildebrandt, \& G. Metakides (Eds.), Digital Enlightenment Yearbook 2012: 57-75. Amsterdam: IOS Press.

Waaijer, C. J. F., Sonneveld, H., Buitendijk. S. E., van Bochove, C. A., \& van der Weijden, I. C. M. 2016. The Role of Gender in the Employment, Career Perception and Research Performance of Recent PhD Graduates from Dutch Universities. PLoS ONE, 11(10): $1-16$. https://doi.org/10.1371/journal.pone.0164784

West, J., \& Bogers, M. 2014. Leveraging External Sources of Innovation: A Review of Research on Open Innovation. Journal of Product Innovation Management, 31(4): 814-831. https://doi.org/10.1111/jpim.12125 


\section{Academic Affiliations and Funding Acknowledgements}
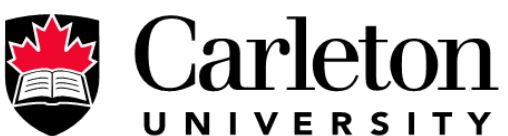

U N I V E R S I T Y

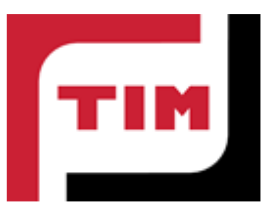

Technology Innovation Management (TIM; timprogram.ca) is an international master's level program at Carleton University in Ottawa, Canada. It leads to a Master of Applied Science (M.A.Sc.) degree, a Master of Engineering (M.Eng.) degree, or a Master of Entrepreneurship (M.Ent.) degree. The objective of this program is to train aspiring entrepreneurs on creating wealth at the early stages of company or opportunity lifecycles.

- The TIM Review is published in association with and receives partial funding from the TIM program. 